\title{
Prevalence of Ulcerative Colitis in Patients Who Underwent Colonoscopy in Benha University Hospitals
}

\author{
MOHAMED A. AFIFI, M.D.; AHMED M. HUSSEIN, M.D. and MAHMOUD H. RIZK, M.D. \\ The Department of Internal Medicine, Faculty of Medicine, Benha University, Egypt
}

\begin{abstract}
Background: Colonoscopy is the most accurate diagnostic tool in IBD.

It is useful in detection of the severity and extent of UC. the incidence of IBD especially UC increased significantly among Egyptian patients as evidenced in previous studies in the past ten years.

Aim of Study: To study the prevalence of UC among patients referred to the internal medicine endoscopy unit to perform colonoscopy and evaluate the most common presenting symptoms of UC.

Patients and Methods: Cross sectional study encompassed 190 patients who underwent colonoscopy during the period from October 2018 to October 2019, the main presenting complaint was recorded and the result of colonoscopy.

Results: Prevalence of UC was about $11.05 \%$ on the other side, internal hemorrhoids was the commonest diagnosis in group I (Non-UC patients) $26.6 \%$ followed by nonspecific colitis in $23.6 \%$. Bleeding per rectum was the main symptom and indication for colonoscopy $(50.5 \%)$ but was not significantly different among studied groups.

Conclusion: Prevalence of UC raised in Egypt in the last years. In this study, it was the 3 rd diagnosis after internal hemorrhoids and non-specific colitis constituting about $11.05 \%$.
\end{abstract}

Key Words: IBD - Ulcerative colitis - Bleeding per rectum - Colonoscopy.

\section{Introduction}

ULCERATIVE colitis (UC) is a chronic autoimmune disorder of the colonic mucosa, that mainly impacts the rectum and may reach other colon's parts $[1,2]$. Characterized by relapsing and remitting mucosal inflammation, begining in the rectum and extending to the proximal parts of the colon. [1] The most common presentation of UC is blood in the stool and diarrhea.

Correspondence to: Dr. Mohamed A. Afifi, E-Mail: dr malatif82@yahoo.com
About $15 \%$ of patients can initially suffer from severe symptoms [3]. These symptoms include, but not exclusive to, fatigue, incontinence, higher frequency of bowel movements with mucus discharge and abdominal discomfort (cramps) [4] About $30 \%$ of patients can develop extra-intestinal manifestations, and about a quarter might have extraintestinal manifestations before UC diagnosis. $[5,6]$.

Colonoscopy is an important diagnostic modality because of its ability to visualize, detect and remove malignant and premalignant lesions. Internationally, whenever there is a high risk of colorectal cancer (CRC), gastroenterology and cancer's societies recommend performing colonoscopy as the first step diagnosis despite the fact it is risky and costly. It is the most accurate diagnostic tool in IBD. It is useful in detection of the severity and extent Of UC [7].

UC occurs with different frequencies around the world. The countries reporting for the highest incidence of UC are the United States, the United Kingdom and Sweden [8,9].

UC has always seemed to be rare in the Middle East and Northern Africa. No accurate registry or cohort of patients had ever studied the exact prevalence of UC in these populations. In Mediterranean countries, the prevalence of UC was estimated at 5/100000 persons [10]. In Egypt, the incidence has increased in the past ten years $[\mathbf{1 1 , 1 2 ]}$

In This study, we studied the prevalence of UC among patients referred to the internal medicine endoscopy unit to perform colonoscopy and evaluate the most common presenting symptoms of $\mathrm{UC}$. 


\section{Patients and Methods}

Our study is a cross-sectional observational study that was carried out in the Internal Medicine Department, endoscopy unit, Benha University Hospitals on all consecutively enrolled patients (190) admitted to the Endoscopy Unit for colonoscopy complaining of various lower GIT symptoms from October 2018 to October 2019.

\section{Exclusion criteria:}

- Patients $<18$ and $>80$ years.

- Patients contraindicated to perform colonoscopy such as pregnancy, high bleeding tendency, risk of shocks, perforation in colon, acute peritonitis, uncooperative anxious patients or having toxic mega colon.

\section{Patients were subjected to:}

- Detailed history with special stress on symptoms of IBD as (bleeding per rectum, chronic diarrhea, tenesmus and chronic dysentery) and symptoms of extra-intestinal manifestations as (ophthalmic, musculoskeletal, mucocutaneous).

- Thorough clinical examination

- Colonoscopy was performed using OLYMPUS GIF-CF 140 videoscope.

To prepare patients for colonoscopy, solid food was restricted for patients 1 day before the procedure. They were asked to be on water, fluids, and clear juices only. Then patients were given PREPAWEST one day before the procedure. PREPAWEST for oral solution is a laxative preparation that contains polyethylene glycol, sodium sulfate, sodium chloride, potassium chloride, sodium ascorbate, and ascorbic acid, and it was acceptable and effective in patients.

Sedation before the colonoscopy procedure: At the time of the procedure, patients were often given intravenous sedative drugs, such as midazolam. The average person will receive a $5-10 \mathrm{mg}$ IV midazolam.

Procedure technique: After informed consent is obtained and physical examination is performed, the patient is connected to the monitoring device and put in the left lateral position. After adequate conscious sedation with I.V midazolam, a digital rectal examination is to be performed, in order to determine preparation adequacy, but also to detect anal stricture or masses.

The colonoscope was introduced in to the rectum and advanced under direct visualization to cecum identified by visual landmarks and ultimately the terminal ileum.
The scope subsequently was withdrawn slowly while examining the color, texture, anatomy and integrity of the mucosa on the way out. Multiple biopsies were taken from pathologic lesion for histopathology. In the rectum, the scope was retroflexed to evaluate for internal piles and anorectal pathology. The patient is then subsequently transferred to the recovery area.

\section{Histopathological examination:}

The first step was to refer the taken biopsy to an expert pathologist. Then, the expert fixed the biopsy, embedded, and sectioned it. The sections were then stained with hematoxylin and eosin. A survey was preliminary conducted. Patients fulfilling the clinical and endoscopic criteria and confirmed histologically, were diagnosed to have UC.

Based on their biopsies histopathological and colonoscopy results, Patients were grouped into the following:

- Group I: Included 169 patients without UC.

- Group II: Included 21 patients diagnosed with UC.

\section{Statistical analysis:}

Data was collected and analyzed using a statistical software program, SPSS (Statistical Package of Social Services) version 16 for Microsoft windows. On one hand, qualitative data were reported as frequencies and percentages. On another hand, mean and standard deviation were used to present quantitative data. $t$-test was conducted to compare quantitative variables while Chi-square $\left(\mathrm{x}^{2}\right)$ was done to compare categorical data. Statistical significance was determined by probability ( $p$-value) $\longleftrightarrow 0.05$.

The study was approved by the review board of the department of internal medicine, according to the Declaration of Helsinki.

\section{Results}

Table (1) shows the demographic characterisitics of group II in comparison with group I and revealed that age was statistically significantly younger in group II compared to group I and the percentage of females among group II was significantly higher and the percentage of smokers were also significantly lower in group II (UC Patients).

Table (2) shows that the most common diagnosis among group I, which was internal hemorrhoids followed by non-specific colitis and in $21.8 \%$ of cases the colonoscopic examination was normal. 
Table (3) shows comparison between UC patients (group II) and group I. It was found that the most common presenting symptoms among them were bleeding per rectum followed by abdominal pain. Group II (UC Patients) showed significantly higher frequencies in all symptoms except in the symptom of rectal bleeding that was not significantly different as shown in Table (3).

Table (4) shows the classification of group II according to severity and extent as per Montreal classificstion, revealing that nearly half of the patients had mild disease $42.8 \%$ that was restricted to the rectum (proctitis) $52.3 \%$, and only three cases had dysplastic changes evident in their biopsies.

Table (1): Demographic characteristics of patients with UC in comparison with patients without UC.

\begin{tabular}{llllll}
\hline & \multicolumn{2}{c}{$\begin{array}{c}\text { Group I } \\
(\mathrm{N}=169)\end{array}$} & \multicolumn{2}{c}{$\begin{array}{c}\text { Group II } \\
(\mathrm{N}=21)\end{array}$} & \\
\cline { 2 - 4 } & $\mathrm{N}$ & $\%$ & $\mathrm{~N}$ & $\%$ & \\
\hline Age: & & & & & \\
$\quad$ Mean $\pm \mathrm{SD}$ & $43.38 \pm 16.9$ & & $34.71 \pm 11.2$ & 0.005 \\
Sex: & & & & & \\
Female/Male : & & & & & \\
$\quad$ Female & 53 & 31.3 & 12 & 57.1 & 0.02 \\
$\quad$ Male & 116 & 68.6 & 9 & 42.8 & \\
Special habits: & & & & & \\
$\quad$ No & 117 & 69.2 & 20 & 95.2 & 0.009 \\
$\quad$ Smoker & 50 & 29.5 & 1 & 4.7 & \\
$\quad$ x-smoker & 2 & 1.18 & 0 & 0.0 & \\
\hline
\end{tabular}

Table (2): Diagnosis of group I after colonoscopy and pathological examination.

\begin{tabular}{lcl}
\hline Diagnosis & No. & $\%$ \\
\hline Internal piles & 45 & 26.6 \\
Anal fissure & 11 & 6.5 \\
Polyposis & 9 & 5.3 \\
Diverticulosis & 7 & 4.1 \\
Non-specific colitis & 40 & 23.6 \\
Free colonoscopy & 37 & 21.8 \\
Crohn's disease & 3 & 1.7 \\
Colorectal cancer & 17 & 10 \\
\hline
\end{tabular}

Table (3): Comparison between the studied groups as regards the presenting symptoms.

\begin{tabular}{lllll}
\hline Symptom & $\begin{array}{c}\text { Group I } \\
(\mathrm{N}=169)\end{array}$ & $\begin{array}{c}\text { Group II } \\
(\mathrm{N}=21)\end{array}$ & $\mathrm{X}^{2}$ & $p$ \\
\hline $\begin{array}{c}\text { Bleeding } \\
\text { per rectum }\end{array}$ & $83(49.1 \%)$ & $13(61.9 \%)$ & 2.748 & 0.975 \\
$\begin{array}{c}\text { Chronic } \\
\text { diarrhea }\end{array}$ & $22(13.01 \%)$ & $10(47.6 \%)$ & 19.803 & 0.00001 \\
$\begin{array}{c}\text { Abdominal } \\
\text { pain }\end{array}$ & $30(17.7 \%)$ & $9(42.8 \%)$ & 10.296 & 0.001 \\
$\begin{array}{l}\text { Fever } \\
\text { Weight loss }\end{array}$ & $1(0.59 \%)$ & $4(19.04 \%)$ & 19.4928 & 0.002 \\
Anemia & $2(1.18 \%)$ & $7(33.3 \%)$ & 28.271 & 0.0001 \\
\hline
\end{tabular}

Table (4): Classification of group II (UC patients) according to Montreal classification and microscopic findings.

\begin{tabular}{|c|c|c|}
\hline & $\mathrm{N}=21$ & $\%$ \\
\hline \multicolumn{3}{|l|}{ Extent: } \\
\hline $\begin{array}{l}\text { E1: From rectum distal to recto-sigmoid junc- } \\
\text { tion only named "Proctitis" }\end{array}$ & 11 & 52.3 \\
\hline $\begin{array}{l}\text { E2: From distal to splenic flexure named "Left } \\
\text { sided colitis" }\end{array}$ & 6 & 28.5 \\
\hline $\begin{array}{l}\text { E3: Extension proximally to splenic flexure } \\
\text { named "Pancolitis" / "extensive colitis" }\end{array}$ & 4 & 19.04 \\
\hline \multicolumn{3}{|l|}{ Severity: } \\
\hline $\begin{array}{l}\text { S 1: Mild UC: } \leq 4 \text { stools per day } \pm \text { blood }+ \text { No } \\
\text { systemic illness }+ \text { normal inflammatory } \\
\text { markers }\end{array}$ & 9 & 42.8 \\
\hline $\begin{array}{l}\text { S2: Moderate UC: }>4 \text { stools per day + minimal } \\
\text { systemic toxicity signs }\end{array}$ & 7 & 33.3 \\
\hline $\begin{aligned} \text { S3: } & \text { Severe UC: } \geq 6 \text { bloody stool per day+ pulse } \\
& >90 \mathrm{bpm}+\text { temperature }>37.5^{\circ} \mathrm{C}+\text { hemo- } \\
& \text { globin }<10 \mathrm{~g} / \mathrm{dl}+\text { ESR }>30 \mathrm{~mm} / \mathrm{hr}\end{aligned}$ & 5 & 23.8 \\
\hline \multicolumn{3}{|l|}{ Microscopic findings: } \\
\hline Ulceration & 21 & 100 \\
\hline Crypt abscess & 21 & 100 \\
\hline Mucosal neutrophil infiltration & 21 & 100 \\
\hline Dysplastic changes & 3 & 14.2 \\
\hline
\end{tabular}

\section{Discussion}

Ulcerative colitis (UC) is a chronic autoimmune disorder of the colonic mucosa, that mainly impacts the rectum but may reach to other colon's parts $[1,2]$.

Colonoscopy may be done for many reasons such as to investigate the cause of bleeding per rectum, chronic abdominal pain, unexplained changes in bowel habit, suspicious of malignancy or screening for colorectal carcinoma in risky individuals [13]

Colonoscopy is the most accurate diagnostic tool in IBD. It is useful in detection of the severity and extent of UC [1]. The current study assessed the prevalence and clinical characteristics of UC in all patients who underwent colonoscopy at internal medicine department, endoscopy unit, Benha University Hospitals in the period from October 2018 to October 2019.

Patients, based on their histophathological and colonoscopy results, were categorized into two groups. Group I included 169 patients without UC, and Group II included 21 patients diagnosed with $\mathrm{UC}$.

In our study, age was statistically significantly younger in group II (UC patients) compared to group I (non-UC patients), this agrees with Tozun et al. [14] who concluded that most diagnosed patients were between 20 and 40 years old. 
The percentage of females among group II was significantly higher, this agrees with Esmat et al. [12]. The percentage of smokers was significantly lower in group II (UC Patients). In our study, we found that the most common presenting symptom among all patients was bleeding per rectum $(50.5 \%)$ followed by chronic abdominal pain $(20.5 \%)$ and chronic diarrhea (16.8\%), this agrees with Dabuka et al. [15] who showed patients seeking medical advice are commonly prompted by bleeding per rectum and abdominal pain and that colorectal cancer, IBD and many other GI disorders show rectal bleeding as the early sign.

The frequency of all symptoms was significantly higher in group II (UC Patients) except for bleeding per rectum which showed no significant difference. In our current study, UC was the 3 rd pathologic diagnosis constituting about $11.05 \%$ after internal hemorrhoids (23.6\%) and non-specific colitis $(21.05 \%)$. The study performed by Ismaila and Misuno [16] found that hemorrhoids were the commonest lesion.

As regard severity and extent as per MONTREAL classificstion, the study revealed that nearly half of UC patients had mild disease $42.8 \%$ that was restricted to the rectum (proctitis) $52.3 \%$. In the current study, crypt abscesses, mucosal ulcers, and sub-mucosal infiltration with neutrophils were present in all the biopsies' histopathological examinations of ulcerative colitis patients. The study also revealed that only $14.2 \%$ of ulcerative colitis patients had dysplastic changes similarly to the Kleer et al. [17] reported results.

\section{Conclusion:}

Colonoscopy is the most accurate diagnostic tool in IBD. It is useful in detection of the severity, extent of UC and for follow-up. Prevalence of UC raised in Egypt in the last years. In our study, it was the 3 rd pathologic diagnosis after internal hemorrhoids and non-specific colitis constituting about $11.05 \%$. Most UC patients suffer from mild to moderate manifestations and the disease mainly affected the rectum and the left side of the colon.

Funding: Not Available.

Conflicts of interest: Not Available.

Ethical considerations: Approved; All participants have provided written consents.

\section{References}

1- UNGARO R., MEHANDRU S., ALLEN P.B., et al.: Ulcerative colitis. Lancet, 389: 1756-70, 2017.
2- THRASH B., PATEL M., SHAH K.R., et al.: Cutaneous manifestations of gastrointestinal disease: Part II. J. Am. Acad. Dermatol., 68: 211. e1-33, 2013.

3- DIGNASS A., ELIAKIM R., MAGRO F., et al.: Second European evidence-based consensus on the diagnosis and management of ulcerative colitis part 1: Definitions and diagnosis. J. Crohns Colitis, 6: 965-90, 2012.

4- BAUMGART D.C. and SANDBORN W.J.: Inflammatory bowel disease: Clinical aspects and established and evolving therapies. Lancet, 369: 1641-57, 2007.

5- BAUMGART D.C. and SANDBORN W.J.: Inflammatory bowel disease: Clinical aspects and established and evolving therapies. Lancet, 369: 1641-57, 2007.

6- VAVRICKA S.R., ROGLER G., GANTENBEIN C., et al.: Chronological order of appearance of extraintestinal manifestations relative to the time of IBD diagnosis in the Swiss Inflammatory Bowel Disease Cohort. Inflamm Bowel Dis., 21: 1794-800, 2015.

7- BHAGATWALA J.: Colonoscopy-indications and contraindications. Ettarh R., ed. Screening for Colorectal Cancer with Colonoscopy. 3rd ed. Rijeka, Croatia: In Tech, 2015.

8- EHLIN A.G., MONTGOMERY S.M., EKBOM A., POUNDER R.E. and WAKEFIELD A.J.: Prevalence of gastrointestinal diseases in two British national birth cohorts. Gut, 52: 1117-1121 [PMID: 12865268 DOI: 10.1136/gut.52.8.1117], 2003.

9- TRALLORI G., PALLI D., SAIEVA C., BARDAZZI G., BONANOMI A.G., D' ALBASIO G., GALLI M., VANNOZZI G., MILLA M., TARANTINO O., RENAI F., MESSORI A., AMOROSI A., PACINI F. and MORETTINI A.: A population-based study of inflammatory bowel disease in Florence over 15 years (1978-92). Scand J. Gastroenterol., 31: 892-899 [PMID: 8888437 DOI: 10.3109/00365529609051998], 1996.

10- TEZEL A., DÖKMECI G., ESKIOCAK M., UMIT H. and SOYLU A.R.: Epidemiological features of ulcerative colitis in Trakya, Turkey. J. Int. Med. Res., 31: 141-148 [PMID: 12760318 DOI: 10.1177/ 147323000303100211], 2003.

11-ELBATEA H., ENABA M., ELKASSAS G., EL-KALLA F. and ELFERT A.: Indications and outcomes of colonoscopy in the middle of Nile delta of Egypt. Dig. Dis. Sci., 56: 2120-3, 2011.

12- ESMAT S., MOHAMED N., MOHAMED E., YEHIA E. and MAZEN N.: Epidemiological and clinical characteristics of inflammatory bowel diseases in Cairo, Egypt. World J. Gastroenterol., 20 (3): 814-821, 2014.

13-OLOKOBA A., OLUSEGUN A., MATHEW O., SAMUEL A., OLADIMEJI A. and LATEEFAT B.: Indications and findings at colonoscopy in Ilorin, Nigeria Niger Med. J. Mar-Apr., 54 (2): 111-114, 2013.

14- TOZUN N., ATUG O., IMERYUZ N., HAMZAOGLU H.O., TIFTIKCI A. and PARLAK E.: Clinical characteristics of inflammatory bowel disease in Turkey: A multicenter epidemiologic survey. J Clin Gastroenterol. Jan., 43 (1): 51-7, 2009.

15- DAKUBO J., KUMOJI R., NAAEDER S. and CLEGG L.: Endoscopic evaluation of the colorectum in patients presenting with haematochaezia in at Korle-Bu Teaching Hospital Accra. Ghana Med. J., 42: 33-7, 2008. 
16- ISMAILA B. and MISAUNO M.: Colonoscopy in a tertiary hospital in Nigeria. J. Med. Trop., 13: 172-4, 2011.
17- KLEER C. and APPELMAN H.: Ulcerative colitis: Patterns of involvement in colorectal biopsies and changes with time Am. J. Surg. Pathol., 22 (8): 983-9, 1998.

\section{معدل انتشار إلتهاب القولون التقرحى فى الهرضى الخاضعين

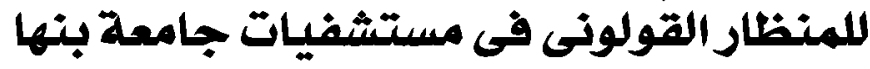

يعد المنظار القولونى من أدق الوسائل التشخيصية لمرض إلتهاب القولمن التقرحى حيث أنه مهم فى تحديد درجة خطورته وانتشاره. ولقد

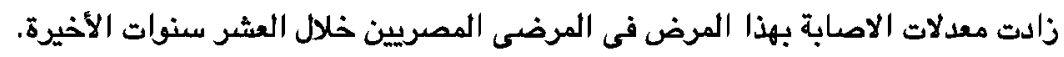

والهدف من هذا البحث هو دراسة هدى انتشار مرض إلتهاب القولون التقرحى فى المرضى الخاضعين المنظار القولونى بوحدة الهناظير

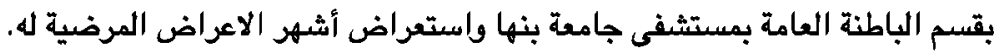
وقد تبين بعد البحث والدراسة أنه يحتل المرتبة التشخيصية الثالثة فى المرضى الذين أدوا المنظار القولونى بنسبة حوالى ل'٪. 